\title{
MENGINTEGRASIKAN REFORMASI BIROKRASI DENGAN INOVASI SEKTOR PUBLIK
}

\author{
Antonius Galih Prasetyo \\ Lembaga Administrasi Negara
}

\begin{abstract}
Abstrak
Kebijakan reformasi birokrasi diterapkan pemerintah dalam rangka mewujudkan birokrasi berkelas dunia yang dinamis dan berdaya saing. Implementasinya telah memberikan beberapa perbaikan, meskipun belum cukup signifikan. Karena pendekatannya yang terlalu formalistis dan seragam, perubahan yang dihasilkan belum cukup memberikan dampak dan manfaat nyata bagi publik. Inovasi sektor publik dihadirkan untuk melengkapi kekurangan tersebut. Hal ini sesungguhnya juga telah dilakukan oleh instansi pemerintah, baik di level pusat maupun daerah. Meski demikian, inovasi sektor publik masih perlu diakselerasi agar pelaksanaannya berjalan lebih merata dan masif untuk mendorong reformasi. Tulisan ini menunjukkan pentingnya untuk melengkapi dan mengaitkan reformasi birokrasi dengan inovasi sektor publik. Hubungan di antara keduanya dapat dipandang baik sebagai hubungan integratif maupun komplementer. Menjadikan inovasi sebagai bagian dari area perubahan dan menyuntikkan dimensi inovasi dalam area perubahan yang selama ini telah ditetapkan adalah dua contoh cara untuk mengintegrasikan keduanya. Reformasi birokrasi dan inovasi sektor publik perlu dilakukan secara simultan untuk perbaikan penyelenggaraan pemerintahan yang komprehensif.
\end{abstract}

Kata kunci: reformasi birokrasi, inovasi sektor publik, area perubahan, integrasi

\begin{abstract}
Bureaucratic reform policy has been implemented by the government in order to produce competitive and dynamic world-class bureaucracy. Eventough the result indicates improvement in the bureaucracy, it leaves much to be desired. Because of its overly formalistic and uniform approach, the reforms have not brough significant advantages to the public. Public sector innovation was introduced to complement these shortcomings. This has actually been done by government agencies, both at the central and regional levels. Nevertheless, public sector innovation needs to be accelerated in order to be implemented evenly and massively to spur the reform. This paper argues the importance of complementing and linking bureaucratic reform with public sector innovation. The relationship between the two can be viewed both as an integrative and complementary relationship. Making innovation a part of the change area and injecting the innovation dimension in the area of change are two examples of ways to integrate bureaucratic reform and public sector innovation. This integration is essential to achieve comprehensive improvement of governance.
\end{abstract}

Keywords: bureucratic reform, public sector innovation, areas of change, integration 


\section{Pendahuluan}

Setelah Indonesia menjalani era demokrasi sejak tahun 1998, pemerintah telah menjalankan beberapa perubahan penting. Perubahan tersebut sebagian besar disebabkan oleh tuntutan publik yang menguat atas perbaikan dalam berbagai bidang seperti pengakuan yang lebih luas akan hak sosial-politik, pemilihan umum yang bebas, keterbukaan informasi, penegakan hukum yang baik, dan sebagainya. Tidak kalah penting dari tuntutan yang memberikan manfaat langsung kepada masyarakat, tuntutan juga diarahkan kepada pihak internal pemerintahan sendiri, khususnya dalam aspek penyelenggaraan negara oleh aparatur pemerintah.

Pada dimensi tersebut kemudian mengemuka diskursus mengenai reformasi birokrasi. Reformasi birokrasi dipandang sebagai resep ampuh menuju birokrasi berkelas dunia yang dinamis dan melayani dengan prima. Pemerintah merespons tuntutan tersebut dengan membuat kebijakan yang terkait dengan reformasi birokrasi. Semua organisasi publik diwajibkan untuk menjalankan reformasi birokrasi sesuai dengan yang digariskan dalam berbagai kebijakan.

Dalam perjalanannya reformasi birokrasi memperoleh berbagai catatan positif. Meski demikian, masih ada kelemahan dan kekurangan dalam pelaksanaannya. Kekurangan ini, selain diatasi dengan memperbaiki pengelolaan reformasi birokrasi, baik dari sisi konsep maupun praktik, juga dapat ditutup dengan mengembangkan inovasi sektor publik. Cara terakhir dipandang memberikan kesempatan lebih luas bagi organisasi publik untuk memperbaiki kinerja dan pelayanannya secara lebih kreatif dan fleksibel. Tulisan ini bertujuan untuk menunjukkan mengenai pentingnya mengintegrasikan reformasi birokrasi dan inovasi sektor publik sebagai dua pendekatan yang harus dijalankan secara simultan agar birokrasi mampu mencapai profil yang selama ini diharapkan, yakni menjadi institusi yang memberikan pelayanan publik dan mengungkit kesejahteraan rakyat secara maksimal.

Untuk itu, tulisan ini akan distrukturkan sebagai berikut. Pertama, akan diulas dinamika pelaksanaan reformasi birokrasi yang telah dilakukan selama ini, mulai dari perjalanan historisnya dari masa ke masa sampai kepada landasan kebijakan atau peraturan yang mendasarinya. Selanjutnya, diuraikan evaluasi terhadap pelaksanaan reformasi birokrasi untuk menunjukkan mengenai pentingnya melengkapi pendekatan reformasi birokrasi dengan pendekatan inovasi sektor publik. Beranjak dari situ kemudian diulas mengenai inovasi sektor publik di Indonesia, mulai dari regulasi yang mengatur tentang inovasi sektor publik, dinamika pelaksanaannya selama beberapa tahun terakhir, dan evaluasi terhadapnya. Tulisan kemudian dilanjutkan dengan uraian konseptual mengenai pentingnya mengintegrasikan reformasi birokrasi dengan inovasi sektor publik, termasuk rekomendasi mengenai cara untuk mengintegrasikan keduanya. Tulisan diakhiri dengan bagian Penutup.

\section{Reformasi Birokrasi dari Masa ke Masa}

Reformasi birokrasi (bureaucratic reform) atau yang seringkali dipertukarkan dengan administrative reform dapat dipahami sebagai a conscious, wellconsidered change that is carried out in a public sector organization or system for the purpose of improving its structure, operation or the quality of its workforce (Gow, 2012). Melalui reformasi birokrasi, penyelenggaraan pemerintahan diharapkan berjalan dengan lebih tertata dan bersih sesuai dengan prinsip-prinsip good governance. Ini artinya birokrasi diharapkan berubah dari sifat dan streotipenya selama ini yang telah dipersepsikan publik sejak lama seperti korup, patrimonial, feodal, dan tidak profesional. Praktik-praktik ini telah 
berlangsung dan berakar lama bahkan sejak masa kolonial ketika pertama kali sistem administrasi modern diperkenalkan (Sutherland, 1979).

Sesungguhnya upaya untuk melakukan perbaikan birokrasi telah diupayakan pada masa pasca-kolonial meskipun tidak dikerangkai dalam tema reformasi birokrasi. Hal ini ditandai dengan pembentukan berbagai lembaga dan tim yang ditugaskan untuk mengatasi berbagai penyakit birokrasi. Pada masa kepresidenan Soekarno dibentuk Panitia Negara untuk Menyelidiki Organisasi Kementeriankementerian (PANOK), Lembaga Administrasi Negara (LAN), Panitia Retooling Aparatur Negara (PARAN), dan Komando Tertinggi Retooling Aparatur Revolusi (KOTRAR) (1964). Kemudian pada masa Orde Baru (1967-1998) dibentuk Tim Penertiban Aparatur/Administrasi Pemerintah (PAAP), Menteri Negara untuk Penyempurnaan dan Pembersihan Aparatur Negara (MENPAN), Badan Pemeriksaan Keuangan dan Pembangunan (BPKP), dan Operasi Tertib (Opstib) (Wibawa, Prasetyo, dan Kautsar, 2012). Semua upaya tersebut gagal dalam membawa perbaikan dalam tubuh birokrasi. Jika pada masa Orde Lama disebabkan karena negara masih bergelut dengan instabilitas politik dan kekurangan sumber daya sebagai negara baru sehingga tidak dapat fokus menata birokrasi, maka pada Orde Baru kegagalan disebabkan oleh tiadanya niat yang sungguh-sungguh dari penguasa untuk melakukan perbaikan, di mana pembentukan berbagai lembaga hanyalah kedok untuk menutupi praktik penyelenggaraan negara yang koruptif dan oligarkis.

Era demokrasi yang dimulai sejak 1998 tentulah membawa harapan. Meski demikian, tuntutan untuk melakukan reformasi birokrasi tidak terdengar kuat gaungnya. Masyarakat dan pemerintah lebih berminat untuk melakukan perbaikan pada hal-hal yang lebih bersifat nonteknokratis. Beberapa kebijakan memang dilahirkan untuk memperbaiki kondisi birokrasi agar lebih bersih, akuntabel, dan berkinerja seperti UU Nomor 28 Tahun 1999 tentang Penyelenggara Negara yang Bersih dari KKN, UU Nomor 31 Tahun 1999 tentang Pemberantasan Tindak Pidana Korupsi, dan UU Nomor 17 Tahun 2003 tentang Keuangan Negara (yang menekankan tentang penganggaran berbasis kinerja) namun secara keseluruhan upaya penataan melalui regulasi masih dilakukan secara parsial alias tidak terintegrasi (Rohdewold, 2005). Hasilnya, tidak ada perbaikan yang terlalu berarti.

Baru pada masa pemerintahan Susilo Bambang Yudhoyono, tepatnya sejak tahun 2010, reformasi birokrasi mulai menjadi bagian dari arus utama, setidaknya secara diskursif dan regulatif. Ini diisyaratkan ketika setahun sebelumnya Kementerian Negara Pendayagunaan Aparatur Negara mendapat tambahan nomenklatur Reformasi Birokrasi. Sejak 2010 diterbitkan berbagai kebijakan yang mengatur reformasi brokrasi secara makro dan sistemik, yakni Perpres No. 81 Tahun 2010 tentang Grand Design Reformasi Birokrasi 2010-2025, Permenpan \& RB No. 20 Tahun 2010 tentang Road Map Reformasi Birokrasi 2010 - 2014 (diperbarui dengan Permenpan \& RB No. 11 Tahun 2015 tentang Road Map Reformasi Birokrasi 2015-2019), dan PermenPAN RB No. 7 s/d 15 Tahun 2011 yang merupakan pedoman teknis tentang berbagai hal terkait reformasi birokrasi. Visi reformasi birokrasi sebagaimana tertuang dalam Grand Design adalah terwujudnya pemerintahan kelas dunia yang bercirikan tata kelola pemerintahan yang baik.

Reformasi birokrasi diakui oleh pemerintah sebagai perjalanan yang panjang. Oleh karenanya, tak heran bila Grand Design Reformasi Birokrasi mencakup masa selama 16 tahun (20102025). Trayektori transformasi yang dicanangkan pemerintah dibagi dalam tiga tahapan: rule-based bureaucracy (2013), performance-based bureaucracy (2018), dan dynamics governance (2025). Sementara dalam Road Map yang berlaku 
saat ini, ditetapkan tiga sasaran reformasi birokrasi, yakni birokrasi yang bersih dan akuntabel, birokrasi yang efektif dan efisien, dan birokrasi yang memiliki pelayanan publik berkualitas. Untuk mewujudkan ketiga sasaran tersebut, dirumuskan delapan area reformasi birokrasi yang terdiri dari: mental aparatur, pengawasan, akuntabilitas, kelembagaan, tata laksana, SDM aparatur, peraturan perundang-undangan, dan pelayanan publik. Banyaknya area perubahan yang disasar melalui program reformasi birokrasi menunjukkan bahwa birokrasi memiliki kelemahan di banyak aspek, dari mulai paradigma sampai pekerjaan teknis harian, sehingga membutuhkan pembenahan yang menyeluruh.

\section{Capaian Kebijakan Reformasi Birokrasi}

Agar perbaikan dapat berjalan dengan terarah dan sesuai dengan skala prioritas, maka 8 area perubahan reformasi birokrasi di atas diterjemahkan menjadi 9 program percepatan reformasi birokrasi, yakni 1) penataan struktur organisasi pemerintahan; 2) penataan jumlah dan distribusi PNS; 3) pengembangan sistem seleksi CPNS dan promosi PNS secara terbuka; 4) peningkatan profesionalisasi PNS; 5) pengembangan sistem pemerintahan elektronik yang terintegrasi; 6) peningkatan pelayanan publik; 7) peningkatan integritas dan akuntabilitas kinerja aparatur; 8) peningkatan kesejahteraan pegawai negeri; dan 9) efisiensi belanja pegawai. Selama 7 tahun pelaksanaan reformasi birokrasi, telah banyak capaian yang dihasilkan. Beberapa capaian dapat dicatat sebagai berikut:

1. Penataan struktur organisasi pemerintahan dilakukan melalui perampingan beberapa $\mathrm{K} / \mathrm{L}$ yang menghapus beberapa jabatan struktural sehingga berefek pada perampingan struktur dan penghematan anggaran. Ini misalnya dilakukan oleh LAN yang pada tahun 2014 mengurangi jumlah Eselon I-nya dari 6 menjadi 4.
Kemudian dilakukan pula pembubaran Lembaga Non Struktural (LNS) untuk mengurangi beban anggaran pemerintah dan menghapus tumpang tindih kewenangan dengan $\mathrm{K} / \mathrm{L}$ yang sudah ada. Ini dilakukan melalui penerbitan Perpes No. 116 Tahun 2016 yang mengatur mengenai pembubaran 9 LNS. Ke depan, diharapkan akan ada kebih banyak LNS yang dibubarkan, digabung, atau diintegrasikan ke dalam $\mathrm{K} / \mathrm{L}$ yang sudah ada sesuai dengan hasil evaluasi yang dilakukan KemenPAN RB.

2. Penataan jumlah dan distribusi PNS dilakukan dengan mengatur bahwa pengajuan formasi baru harus dilengkapi dengan analisis jabatan, analisis beban kerja, evaluasi jabatan. Dengan demikian, pengajuan formasi dilakukan dengan basis yang rasional dan terukur. Selain itu, dilakukan pula pelaksanaan moratorium PNS yang berjalan pada tahun 2011-2012 dan 2016-sekarang. Sebagian permasalahan tenaga honorer juga dituntaskan dengan memberikan kesempatan kepada tenaga honorer $\mathrm{K} 1$ dan $\mathrm{K} 2$ untuk mengikuti tes CPNS.

3. Telah dikembangkan sistem seleksi CPNS dan promosi PNS yang terbuka. Penerimaan CPNS kini dilakukan secara terbuka dan tanpa biaya. Pelaksanaannya juga transparan, ditandai dengan pelaksanaan tes berbasis Computer Assisted Test (CAT) dan pengumuman nilai secara terbuka. Sementara untuk promosi dan mutasi PNS, melalui SE MenPAN RB No. 16 Tahun 2012 telah diatur bahwa mutasi dan promosi PNS dilakukan dengan sistem merit. Untuk jabatan eselon I dan II pengisiannya dilakukan secara terbuka dan kompetitif melalui mekanisme open bidding, di mana peserta di luar Aparatur Sipil Negara (ASN) yang telah memenuhi syarat juga dapat mengikutinya.

4. Peningkatan profesionalisasi PNS dilakukan dengan penerbitan UU 
Nomor 5 Tahun 2014 tentang ASN yang mengakui ASN sebagai sebuah profesi sehingga harus mengadopsi nilai-nilai profesionalitas. Selain itu, jumlah jabatan fungsional selaku tenaga profesional di lingkungan birokrasi diperbanyak. Diperkenalkan juga jabatan fungsional baru yang strategis, misalnya analis kebijakan yang diharapkan dapat berkontribusi dalam memperbaiki kualitas kebijakan. Ada pula penerapan Sasaran Kinerja Pegawai (SKP) melalui PP No. 46 Tahun 2011 tentang Penilaian Prestasi Kerja PNS. Secara khusus, LAN banyak berperan dalam peningkatan profesionalisasi PNS melalui berbagai pembaruan diklat yang dihasilkannya, antara lain Diklat Prajabatan Pola Baru, Diklat Kepemimpinan (Diklatpim) Pola Baru, dan Diklat Reform Leader Academy (RLA). Dalam Diklat Prajabatan Pola Baru, CPNS dididik untuk menerapkan nilai-nilai dasar PNS (Akuntabilitas, Nasionalisme, Etika Publik, Komitmen Mutu, dan Anti-Korupsi) dalam melakukan pekerjaannya sehingga nilai-nilai tersebut terinternalisasi dalam diri. Dalam Diklatpim Pola Baru, peserta dituntut untuk menghasilkan inovasi melalui proyek perubahan agar dirinya mampu berperan sebagai agen perubahan. Sementara melalui Diklat RLA, dihasilkan pemimpin reformasi melalui penyelenggaraan diklat yang bersifat project based dan result oriented dengan metode action learning, di mana peserta secara kolektif mengerjakan proyek tertentu dan dituntut melakukan terobosan atau inovasi dalam program atau pelayanan publik yang berdampak luas.

5. Pengembangan e-government diwujudkan melalui penyelenggaraan berbagai pelayanan publik melalui teknologi informasi dan komunikasi (TIK) seperti pengadaan barang dan jasa secara elektonik (e-procurement) melalui LPSE, penerapan tata naskah dinas elektronik, dan keterpaduan sistem perencanaan, penganggaran, dan evaluasi kinerja. Praktik baik penyelenggaraan e-government banyak terjadi di level pemerintah daerah, seperti misalnya yang diterapkan di Pemerintah Kota Surabaya dan Pemerintah Provinsi DKI Jakarta (Lihat Fanida dan Niswah, 2015; Ziadi, Supriyono, dan Wijaya, 2016).

6. Peningkatan pelayanan publik berusaha diwujudkan dengan menerbitkan sebuah peraturan induk mengenainya, yakni UU Nomor 25 tahun 2009 tentang Pelayanan Publik. Dari situ kemudian dihasilkan berbagai standar dan instrumen yang mampu menjadi katalis bagi instansi publik untuk memperbaiki pelayanannya seperti Standar Pelayanan Publik, Standar Pelayanan Minimal, Standar Operasi Prosedur (SOP), Maklumat Pelayanan, Indeks Kepuasan Masyarakat, dan sebagainya. Sementara pembentukan Ombudsman Republik Indonesia (ORI) sejak tahun 2000 menjadi lembaga pengawas dan penerima pengaduan atas pelayanan publik yang dilakukan birokrasi. Dalam dimensi ini juga patut disebutkan amanat untuk membentuk Pelayanan Terpadu Satu Pintu (PTSP), institusi yang memberikan pelayanan perizinan dan non-perizinan yang dalam keseluruhan prosesnya mulai dari permohonan sampai terbitnya sebuah dokumen dilakukan di satu tempat. Keberadaan PTSP memperpendek dan memperhemat pelayanan yang selama ini dilakukan di banyak tempat dengan prosedur berbelit. Sampai dengan tahun 2015 telah terbentuk 498 PTSP (menurut Kementerian Dalam Negeri) atau 508 (menurut Badan Koordinasi Penanaman Modal) di seluruh Indonesia (Pusat Inovasi Pelayanan Publik LAN, 2015). 
7. Peningkatan integritas dan akuntabilitas kinerja aparatur dilakukan dengan kewajiban bagi instansi pemerinta untuk membuat Laporan Akuntabilitas Kinerja Instansi Pemerintah (LAKIP), kewajiban bagi penyelengara negara untuk menyerahkan Laporan Harta Kekayaan Penyelenggara Negara (LHKPN), pembentukan zona integritas di berbagai $\mathrm{K} / \mathrm{L} / \mathrm{D}$, pemeriksaan dari PPATK untuk pengangkatan pejabat Eselon I, dan penerbitan regulasi yang mendukung peningkatan integritas dan akuntabilitas seperti Permenpan RB Nomor 37 Tahun 2012 tentang Pedoman Umum Penanganan Benturan Kepentingan.

8. Peningkatan kesejahteraan pegawai negeri dilakukan melalui penerapan tunjangan kinerja yang besarannya disesuaikan dengan persentase $\mathrm{K} / \mathrm{L}$ dalam memenuhi semua prasyarat reformasi birokrasi. Beberapa daerah yang memiliki APBD besar seperti Jakarta juga memberikan tunjangan daerah dalam jumlah yang besar bagi pegawainya. Nantinya jika RPP Penggajian diterapkan, ASN akan mendapatkan peningkatan kesejahteraan yang lebih besar.

9. Efisiensi belanja pegawai dilakukan melalui moratorium CPNS, optimalisasi penggunaan sarana dan fasilitas yang telah dimiliki instansi pemerintah, dan pemotongan pengeluaran yang berlebihan untuk pos anggaran tertentu yang tidak bersentuhan langsung dengan pelayanan publik (perjalanan dinas, konsinyering, honorarium).

\section{Evaluasi Kebijakan Reformasi Birokrasi}

Meskipun telah mencatat beberapa capaian positif, secara umum kebijakan reformasi birokrasi masih berjalan jauh dari idealitas yang diharapkan. Dalam setiap area reformasi birokrasi dan program percepatan yang dicanangkan, masih banyak masalah yang persisten. Meskipun diniatkan untuk menyentuh seluruh aspek, reformasi birokrasi masih lebih banyak menyentuh perangkat keras berupa penetapan standar, prosedur, dan tata laksana. Akibatnya, implementasi dan pemenuhan reformasi birokrasi pun lebih banyak berkutat dengan melengkapi berbagai dokumen yang dipersyaratkan. Perubahan yang dihasilkan juga baru sebatas pada perbaikan remunerasi dan pembaruan superfisial seperti penerapan absensi elektronik (Dwiyanto, 2015: 270). Di sisi lain, masalah pembenahan mental, etika, dan perilaku aparatur justru belum banyak disentuh.

Tantangan lain yang menghadang reformasi birokrasi adalah masih kuatnya cengkeraman politik terhadap birokrasi. Politisasi birokrasi banyak terjadi menjelang pemilihan kepala daerah yang menyebabkan aparatur terjebak dalam dilema dukung-mendukung. Praktik seperti ini tentu mencederai semangat untuk menegakkan integritas dan netralitas. Komitmen yang rendah terhadap reformasi dari para politisi yang ada di eksekutif dan legislatif juga masih menjadi masalah. Hal ini dapat ditunjukkan melalui berbagai macam kasus seperti keengganan Presiden Joko Widodo untuk merampingkan struktur $\mathrm{K} / \mathrm{L}$ di awal masa pemerintahannya karena harus membagi jabatan kepada partai pendukung (yang bertentangan dengan retorika reformasi birokrasi yang dikatakan pada masa kampanye), kontroversi revisi UU ASN (yang di antaranya mengatur agar tenaga honorer langsung diangkat menjadi PNS tanpa tes dan pembubaran KASN), dan kepala daerah yang menawarkan jabatan di birokrasi dengan imbalan uang (seperti yang belum lama ini diungkap di Kabupaten Klaten).

Di sisi lain, pelaksanaan kebijakan reformasi birokrasi juga tidak mencapai target yang telah ditetapkan dalam RPJMN 2010-2014. Dalam evaluasi yang dilakukan oleh Bappenas sebagaimana dikutip Dwiyanto (2015: 270-271), target penurunan tingkat korupsi, perbaikan integritas pelayanan publik, kemudahan 
berusaha, dan efektivitas pemerintahan tidak tercapai. Ini dikonfirmasi oleh kenyataan rendahnya peringkat Indonesia dalam berbagai ranking yang terkait erat dengan kinerja birokrasi seperti Government Effectiveness Index dan Corruption Perception Index. Dengan kondisi seperti itu, maka perlu dilakukan reorientasi reformasi birokrasi melalui pendekatan yang berbeda dari yang telah dilakukan selama ini. Pada titik inilah inovasi sektor publik menjadi relevan dan menemukan peranannya.

\section{Regulasi Inovasi Sektor Publik}

Inovasi merupakan sebuah istilah dan konsep yang memiliki pengertian luas dan beragam. Ada puluhan definisi yang diajukan oleh berbagai ahli dan lembaga. Namun demikian, garis besar dari banyak definisi tersebut menyisakan dua karakter pokok dari inovasi, yaitu "something fresh (new, original, or improved) that creates value"17. Dalam konteks sektor publik, inovasi dispesifikkan sebagai inovasi administrasi negara (public administration innovation), yang didefinisikan sebagai "proses memikirkan dan mengimplementasikan kebijakan penyelenggaraan kepentingan publik yang original, penting, dan berdampak" (Suripto dan Prasetyo, 2014: 18). Lebih lanjut, inovasi administrasi negara tersebut dapat dibagi ke dalam delapan jenis, yakni inovasi proses, inovasi metode, inovasi produk, inovasi konseptual, inovasi teknologi, inovasi struktur organisasi, inovasi hubungan, dan inovasi pengembangan sumber daya manusia (Ibid.: 22-32).

Terkait dengan inovasi sektor publik, telah dibuat dokumen resmi dan peraturan yang mengatur dan mengakomodasi inovasi sebagai hal yang strategis dalam penyelenggaraan pemerintahan. Dalam Rencana Jangka Panjang Menengah Nasional (RJPMN) 2015-2019 misalnya, inovasi disebut sebanyak 131 kali dalam

\footnotetext{
${ }^{17}$ https://www.freshconsulting.com/what-is-innovation/,
} diakses 27 Januari 2017 ketiga bukunya. Secara khusus dalam hubungannya dengan pelayanan publik, inovasi menjadi salah satu bagian dari arah kebijakan dan strategi berupa peningkatan kapasitas kelembagaan pemerintah daerah untuk agenda pembangunan wilayah subagenda pengembangan tata kelola pemerintahan dan otonomi daerah, yang secara lebih rinci dilakukan melalui: (a) Optimalisasi pemanfataan teknologi informatika guna menciptakan pelayanan yang lebih cepat, murah dan efisien; (b) Penerapan standar pelayanan dan sistem pengaduan pada tiap pemerintah daerah yang terintegrasi dengan manajemen kinerja; dan (c) Penguatan peran PTSP sebagai sarana penyederhanaan pelayanan kepada masyarakat dan dunia usaha." (Lihat RPJMN 2015-2019 Buku III hal. 32).

Ini terkait erat dengan salah satu subagenda dari agenda pembangunan politik, hukum, pertahanan, dan keamanan, yakni percepatan reformasi birokrasi dan tata kelola pemerintahan. Sasaran yang ingin diwujudkan dari sub-agenda tersebut adalah meningkatnya kualitas birokrasi dan tata kelola pemerintahan yang baik dalam mendukung daya saing dan kinerja pembangunan nasional di berbagai bidang, yang ditandai dengan: meningkatnya penyelenggaraan pemerintahan yang bersih dan akuntabel; terwujudnya penyelenggaraan pemerintahan yang efektif dan efisien; serta meningkatnya kualitas pelayanan publik. Adapun arah kebijakan dan strategi pembangunan yang ditetapkan untuk mencapai sasaran tersebut adalah: 1) mewujudkan kelembagaan pemerintah efektif, efisien, dan sinergis; 2) penguatan kapasitas pengelolaan reformasi birokrasi nasional; 3) penerapan manajemen ASN yang transparan, kompetitif, dan berbasis merit; 4) peningkatan kualitas pelayanan publik; 5) penerapan e-government untuk mendukung bisnis proses pemerintahan dan pembangunan yang efisien, efektif, transparan, dan terintegrasi; 6) penerapan 
open government; 7) penguatan manajemen kinerja pembangunan; dan 8) peningkatan kualitas pelaksanaan desentralisasi dan otonomi daerah. Meskipun dalam uraiannya inovasi tidak disebutkan secara eksplisit, namun kita tahu bahwa inovasi menjadi bagian tak terpisahkan dalam pelaksanaan berbagai arah kebijakan dan strategi pembangunan di atas.

Sementara dalam tataran kebijakan yang lebih teknis, telah pula diterbitkan PermenPAN RB Nomor 30 Tahun 2014 tentang Pedoman Inovasi Pelayanan Publik dan beberapa Permenpan yang mengatur tentang Kompetisi Inovasi Pelayanan Publik (Sinovik) setiap tahunnya sejak 2014. Di level undang-undang, inovasi di level pemerintah daerah diamanatkan dalam UU Nomor 23 Tahun 2014 tentang Pemerintah-an Daerah (Pemda) meskipun masih harus menunggu Peraturan Pemerintahnya.

Dalam UU 23/2014 tersebut, ketentuan mengenai inovasi daerah dimuat dalam satu bab tersendiri (Bab XXI) yang diatur dalam 5 pasal. Pasal 386 UU Pemda menyebutkan bahwa inovasi daerah adalah semua bentuk pembaharuan dalam penyelenggaraan pemerintahan daerah. Prinsip-prinsip perumusan kebijakan inovasi terdiri atas: peningkatan efisiensi; perbaikan efektivitas; perbaikan kualitas pelayanan; tidak ada konflik kepentingan; berorientasi kepada kepentingan umum; dilakukan secara terbuka; memenuhi nilainilai kepatutan; dan dapat dipertanggungjawabkan hasilnya tidak untuk kepentingan diri sendiri. Ketentuan penting lain terkait dengan inovasi daerah termuat dalam Pasal 389, yang menyebutkan bahwa "Dalam hal pelaksanaan inovasi yang telah menjadi kebijakan pemerintah Daerah dan inovasi tersebut tidak mencapai sasaran yang telah ditetapkan, aparatur sipil negara tidak dapat dipidana." Ini artinya, ASN mendapatkan perlindungan dari "kriminalisasi" akibat kegagalan inovasi yang tidak mencapai target. Terlihat di sini bahwa pemerintah memberikan penghargaan pada inisiasi dan proses sehingga inovasi tidak melulu diukur dari perspektif target atau output. Dalam proposisi ini tersirat sebuah posisi dasar bahwa sesungguhnya tidak ada inovasi yang gagal, yang ada hanyalah inovasi dengan dinamika beragam yang kesemuanya dapat menjadi bahan pembelajaran. Perlindungan ini, bagaimanapun, tidak dapat dimaknai sebagai kebebasan berinovasi secara manasuka (arbitrary) sebab inovasi tetap tidak boleh melanggar peraturan yang berlaku.

\section{Praktik Inovasi Sektor Publik}

Argumen mengenai pentingnya pengembangan inovasi sektor publik adalah bagian dari seruan umum akan perlunya Indonesia meningkatkan level inovasinya. Berbagai peringkat global yang terkait dengan inovasi, baik langsung maupun tak langsung, menunjukkan bahwa Indonesia masih menempati posisi yang rendah dan tertinggal dari negara-negara tetangga. Dalam Indeks Inovasi Global tahun 2016, Indonesia menempati ranking 88 dari 128 negara. Peringkat ini memang membaik dibandingkan dengan tahun sebelumnya yang berada di ranking 97. Namun demikian, tetap saja posisi ini tertinggal jika dibandingkan dengan banyak negara ASEAN seperti Filipina (74), Vietnam (59), Thailand (52), Malaysia (35), dan Singapura (6). Sementara peringkat kemudahan berbisnis Indonesia (Ease of Doing Business Index) pada tahun 2016 berada di peringkat 109. Lagi-lagi, meskipun mengalami peningkatan progresif setiap tahun sejak 2013, namun tetap saja lebih buruk dibandingkan dengan lima negara ASEAN yang telah disebutkan sebelumnya. Dalam Global Competitiveness Index 2015-2016 keadaannya juga tidak lebih baik. Indonesia turun empat peringkat dibandingkan tahun sebelumnya menjadi urutan 37, tertinggal dari Thailand (32), Malaysia (18), dan Singapura (2).

Meskipun tuntutan bagi birokrasi untuk berinovasi tidak seformal tuntutan untuk melakukan reformasi, namun menariknya inovasi sesungguhnya telah berjalan dengan cukup baik. Ini merupakan 
hal yang positif karena baik tuntutan akan inovasi maupun reformasi memiliki derajat urgensi dan legitimasi yang sama. Bahkan sesungguhnya momentum dan jendela peluang untuk melakukan inovasi terjadi pasca diluncurkannya program reformasi birokrasi. Di sisi lain, rezim desentralisasi yang diberlakukan setelah demokratisasi juga membentangkan tanah lapang bagi birokrasi di level daerah untuk berinovasi. Dengan kewenangan semakin besar yang dimilikinya, daerah memiliki kesempatan untuk lebih mendengarkan aspirasi masyarakatnya untuk diterjemahkan ke dalam kebijakan dan program inovatif.

Indikasi dari mulai diarusutamakannya inovasi dalam penyelenggaraan pemerintahan terlihat dari semakin banyaknya penghargaan yang diberikan untuk inovasi sektor publik, baik yang diberikan oleh pemerintah maupun aktor nonpemerintah. Dari pemerintah ada Kompetisi Inovasi Pelayanan Publik (Sinovik) Kementerian Pendayagunaan Aparatur Negara dan Reformasi Birokrasi yang berjalan sejak tahun 2014, di mana setiap tahunnya dipilih 99 inovasi pelayanan publik dari ratusan atau ribuan proposal yang masuk. Ada pula penghargaan Innovative Government Award (IGA) oleh Kementerian Dalam Negeri dan Kontes Inovasi Solusi serta Kompetisi Open Government (yang mencakup penghargaan layanan publik terprogresif) yang keduanya diberikan oleh Unit Kerja Presiden Bidang Pengawasan dan Pengendalian Pembangunan (UKP4). Beberapa inovasi tersebut bahkan mampu berkompetisi secara global. Misalnya, pada tahun 2014 ada lima inovasi pelayanan publik dari Indonesia yang masuk dalam daftar nominasi inovasi United Nations Public Service Awards (UNPSA). Ini semua belum termasuk inovasi yang tidak didaftarkan untuk meraih penghargaan, seperti yang misalnya termuat dalam buku kumpulan best practices pemerintah kota yang diterbitkan Asosiasi Pemerintah Kota Seluruh Indonesia (APEKSI) setiap tahun sejak 2003, juga berita-berita inovasi sektor publik dan pemimpin daerah inovatif di media massa.

LAN juga turut menyumbang dalam upaya akselerasi inovasi sektor publik. Hal ini dilakukan melalui program yang disebut dengan Laboratorium Inovasi yang dimulai sejak tahun 2015. Program ini memfasilitasi SKPD untuk menciptakan inovasi administrasi negara dengan metode orisinal yang disebut dengan 5D (Drum-up, Diagnose, Design, Deliver, dan Display). Setelah berjalan selama dua tahun (20152016), Laboratorium Inovasi telah dilaksanakan di 16 pemerintah daerah dengan total ide inovasi sebanyak 1.840. Jumlah ini tentu akan semakin bertambah banyak di masa depan.

\section{Tantangan Inovasi Sektor Publik}

Dengan menilik pada kondisi dan lanskap umum inovasi sektor publik yang terjadi di Indonesia selama beberapa tahun terakhir, didapati beberapa tantangan yang harus diatasi apabila Indonesia menginginkan perluasan sekaligus akselerasi inovasi demi kinerja pelayanan publik yang lebih baik dan memuaskan. Tantangan-tantangan tersebut antara lain:

Pertama, regulasi yang kurang memadai. Dalam penyelenggaraan pemerintahan, keberadaan regulasi sebagai landasan hukum menjadi faktor yang sangat penting. Sayangnya, dalam hal inovasi sektor publik, regulasi yang ada masih kurang memadai karena masih terlalu sedikit dan umum. Belum ada peraturan selevel UU yang mengatur secara khusus mengenai inovasi sektor publik. Sementara itu, berbagai regulasi yang lebih teknis seperti (R)PP Inovasi Daerah (sebagai turunan UU Pemda) dan Permenpan tentang Pedoman Inovasi Sektor Publik justru membatasi ruang gerak karena terlalu kaku, prosedural, dan hierarkis.

Kedua, adanya persepsi yang salah mengenai inovasi, seperti bahwa inovasi itu merupakan sesuatu yang rumit, membutuhkan biaya tinggi, dan kompleks. Padahal sesungguhnya inovasi itu mudah, tidak 
mesti mahal, dan bisa dilakukan melalui hal-hal sederhana. Ditambah lagi ada stereotipe yang menyatakan bahwa inovasi hanyalah domain sektor swasta yang harus bertahan karena banyaknya persaingan, sementara sektor publik hanya cukup bekerja rutin karena tugas dan fungsinya sudah baku dan tidak memiliki saingan di luar dirinya. Ini keliru karena seiring dengan peningkatan kritisisme dari masyarakat, mereka pun menuntut sektor publik untuk berbenah, salah satunya melalui inovasi. Karena adanya berbagai pandangan yang salah tersebut, maka tak heran bahwa banyak pemimpin sektor publik, baik di level pusat maupun daerah, yang stagnan karena tidak mampu menghasilkan terobosan berupa inovasi.

Ketiga, belum adanya sistem di birokrasi yang secara inheren memberikan reward bagi aparatur yang melakukan inovasi. Ketiadaan reward menyebabkan hanya aparatur yang benar-benar berkomitmen dan termotivasi sajalah yang mau menginisiasi inovasi karena tidak ada insentif yang diberikan sistem untuk melakukannya. Pemberian reward lebih banyak diberikan dalam bentuk kompetisi dan bukannya secara otomatis, misalnya Sinovik oleh KemenPAN RB, itu pun diberikan atas nama instansi dan bukan perorangan.

Keempat, minimnya instansi publik yang mau melakukan replikasi inovasi. Sesungguhnya selama ini telah tercipta ratusan praktik baik inovasi sektor publik di berbagai bidang dan jenis. Apa yang perlu dilakukan oleh instansi publik yang belum melakukan inovasi hanyalah melakukan replikasi dari salah satu inovasi yang menjadi praktik baik tersebut, tergantung dengan kebutuhannya. Sayangnya, replikasi ini masih jarang dilakukan. Padahal dengan melakukannya dapat menghemat tenaga, pikiran, dan dana. Ada berbagai faktor yang melatarbelakangi keengganan melakukan replikasi ini, mulai dari minimnya informasi terkait praktikpraktik baik inovasi hingga ego pimpinan birokrasi yang lebih suka berpikir sendiri karena takut dicap meniru.

Kelima, masih banyak inovasi yang belum melembaga. Inovasi muncul karena inisiatif pribadi dari kepala daerah atau kepala OPD. Akan tetapi, inovasi tersebut belum diformalkan dalam bentuk regulasi. Akibatnya, inovasi tersebut tidak berkelanjutan. Apabila pemimpin birokrasi suatu saat meninggalkan jabatannya, maka tidak ada jaminan bahwa inovasi akan terus dilanjutkan atau dikembangkan.

\section{Keterkaitan Reformasi Birokrasi dengan Inovasi Sektor Publik}

Reformasi birokrasi terkait erat dengan inovasi. Hubungan di antara keduanya dapat dilihat baik sebagai hubungan integratif maupun komplementer. Inovasi dan reformasi birokrasi adalah kesatuan integral bagaikan dua sisi dari mata uang. Dalam upaya untuk menjadi birokrasi berkelas dunia, baik reformasi birokrasi maupun inovasi sektor publik harus dilakukan secara simultan. Tidak ada birokrasi reformatif tanpa birokrasi inovatif. Perspektif ini memandang bahwa setiap upaya reformasi birokrasi yang otentik selalu mengandung pada dirinya dimensi inovasi. Demikian pula sebaliknya setiap inovasi yang dilakukan sektor publik dengan sungguh-sungguh selalu dapat dikaitkan dengan tujuan untuk mereformasi birokrasi.

Sementara itu, dalam perspektif hubungan komplementer, inovasi dapat dipandang sebagai pelengkap dari kekurangan yang ada pada reformasi birokrasi. Selama ini, reformasi birokrasi dikritik sebagai konsep yang terlalu formalistis dan uniformis. Kebijakan reformasi birokrasi menerapkan prinsip one size fits all dengan mengharuskan setiap kementerian, lembaga, dan daerah (K/L/D) melakukan perbaikan pada 8 area perubahan, padahal masalah dan tantangan yang dihadapi berbeda-beda. Reformasi birokrasi menjadi kehilangan konteksnya. Untuk mendapatkan konteksnya kembali, reformasi birokrasi mestinya direaktuali- 
sasikan dengan cara menentukan rencana perubahan sesuai dengan kebutuhan pemangku kepentingan setiap K/L/D (Dwiyanto, 2015: 271-272). Kebutuhan tersebut berbeda-beda dan bersifat dinamis sehingga perubahan yang dilakukan pun tidak mungkin bersifat seragam. Dengan cara ini, maka orientasi kepada input berupa kepatuhan terhadap 8 area perubahan dan kelengkapan dokumen diubah menjadi orientasi kepada outcome berupa pemberian manfaat yang nyata dan sesuai dengan kebutuhan pemangku kepentingan (Ibid.: 274-275). Pendekatan baru ini sesungguhnya dapat disebut sebagai inovasi, yakni pemecahan masalah secara baru sesuai dengan tantangan khas yang dihadapi dan potensi yang dimiliki. Inovasi adalah komplemen terhadap reformasi birokrasi yang memungkinkan birokrasi berubah dengan lebih luwes dengan tidak melupakan kinerja organisasi dan kepuasan masyarakat.

Mengaitkan erat antara reformasi birokrasi dengan inovasi bukanlah suatu gagasan dan praktik yang baru di dunia internasional. Cummings (2015) mengadvokasikan mengenai pentingnya pendekatan baru yang lebih inovatif, adaptif, dan entrepreneurial terhadap reformasi birokrasi. Dengan cara itu, reformasi birokrasi tidak lagi dilakukan melalui program besar yang telah ditentukan secara deduktif, melainkan melalui penemuan solusi spesifik atas masalah yang digali secara kontekstual. Meskipun ada yang berpendapat bahwa reformasi birokrasi-terutama yang dilakukan secara repetitif dan berketerusan-memiliki pengaruh negatif terhadap budaya organisasi yang berorientasi kepada inovasi (Wynen, Verhoest, dan Kleizen, 2017), namun hubungan di antara keduanya sesungguhnya dapat bersifat saling mendukung jika diaransemen dan didudukkan secara benar. Lee (1970) mengatakan bahwa meskipun inovasi adalah pokok dari reformasi administrasi, namun itu bukanlah hal yang otomatis. Dibutuhkan strategi untuk memfasilitasi adopsi dan persebaran inovasi dalam organisasi publik.

Kualifikasi dan kondisi yang tepat juga menjadi persyaratan yang harus dipenuhi jika inovasi ingin diadopsi sebagai bagian integral reformasi birokrasi. Dalam studinya yang dilakukan selama dua tahun terhadap 97 pelayanan publik yang mengadopsi pendekatan inovasi dalam reformasi manajemen publik, Boyne, dkk. (2005) menemukan bahwa hal itu hanya akan efektif apabila terdapat kondisikondisi berikut: terdapat populasi yang tersebar, inovasi hanya dilakukan terhadap layanan tertentu yang terbatas, dan organisasi sebelumnya telah memiliki pengalaman dalam menjalankan inovasi dalam kerangka reformasi manajemen publik. Sementara itu, studi di Inggris oleh Maddock (2009) menjelaskan mengenai karakteristik inovasi yang cocok untuk diintegrasikan dalam reformasi birokrasi yang kuat dan berkelanjutan, yakni inovasi yang bertumpu pada jaringan dan hubungan aktif, bukan yang diarahkan dari atas atau melalui pendekatan sistem.

Inovasi juga dapat diposisikan sebagai enabler yang membentuk iklim serta kondisi yang kondusif bagi berhasilnya reformasi birokrasi. Binci (2011) meneliti mengenai krusialnya peran iklim inovasi di organisasi publik dalam menyokong keberhasilan pelaksanaan $e$ government di Italia. Di negara itu, reformasi birokrasi yang inovatif dilaporkan menunjukkan karakter durabilitas yang memuaskan, berjalan selama lebih dari 10 tahun (Mele, 2010). Sementara di Amerika Latin dan Karibia, inovasi disebutkan sebagai mesin reformasi (engine of reform) bagi beberapa pemerintah daerah di wilayah itu (Campbell, 1997).

Dalam konteks Indonesia, bagaimana cara yang dapat ditempuh untuk mengaitkan atau mengintegrasikan reformasi birokrasi dengan inovasi sektor publik? Ada berbagai cara yang dapat ditempuh untuk itu. Salah satunya adalah menjadikan inovasi sebagai bagian dari area reformasi birokrasi, melengkapi 8 area yang sudah 
ada. Untuk itu, perlu diciptakan instrumen untuk mengukur penerapan dimensi inovasi dalam reformasi birokrasi. LAN pernah mengembangkan indeks inovasi pemerintah daerah untuk mengukur kinerja inovasi pada pemerintah daerah (Pusat Inovasi Pelayanan Publik LAN, 2016). Inisiatif serupa perlu dikembangkan demi mengembangkan alat, metode, dan instrumen yang lebih tepat serta sederhana dalam menilai inovasi organisasi publik dalam kerangka reformasi birokrasi. Jangan sampai instrumen yang dikembangkan terjebak pada orientasi akan kelengkapan dokumen dan berbagai persyaratan teknis yang sesungguhnya tidak berkaitan secara langsung dengan inovasi.

Cara lain yang dapat ditempuh adalah dengan menyuntikkan dosis inovasi kepada 8 area reformasi birokrasi. Melalui cara ini inovasi diterapkan secara komprehensif di semua area. Dengan demikian, pelaksanaan reformasi birokrasi dapat dilakukan dengan lebih fleksibel dan adaptif, sesuai dengan kebutuhan dan kapasitas organisasi. Namun, inovasi tersebut dijalankan dengan tanpa melupakan standar dasar dan kriteria kinerja yang telah ditetapkan pada setiap area. Inovasi yang dilakukan tidak mengorbankan kualitas pelayanan dan profesionalisme, melainkan memberi nilai tambah kepadanya.

\section{Penutup}

Penyelenggara negara menyadari bahwa demokrasi yang telah menjadi komitmen bersama mesti diiringi dengan pelembagaan norma-norma lain yang terkait dengannya, salah satunya pelayanan publik yang baik. Hal ini diwujudkan dengan melakukan perbaikan yang menyeluruh kepada birokrasi selaku instansi pemberi pelayanan publik. Perbaikan tersebut diskenariokan mencakup dimensi struktur maupun kultur.

Strategi reformasi birokrasi dipilih untuk menjalankan perbaikan terhadap birokrasi. Pemerintah sejak beberapa tahun terakhir berusaha meninggalkan kecenderungan khas negara berkembang yang menjalankan reformasi birokrasi sekadar untuk motif politik dan modernisasi (Farazmand, 2002: 1-2). Reformasi birokrasi dirancang dengan lebih teknokratis demi perbaikan sistem secara keseluruhan. Untuk itu dibuatlah berbagai kebijakan, road map, dan panduan.

Dalam implementasinya reformasi birokrasi memang membuahkan berbagai capaian positif. Namun, perubahan yang dilakukan masih kurang besar dampaknya dan tidak mampu menaikkan peringkat pada berbagai penilaian global yang terkait dengan kinerja birokrasi. Dengan tetap mengakui bahwa peningkatan kapasitas pengelolaan reformasi birokrasi masih perlu ditingkatkan, pada arah yang lain inovasi sektor publik mulai dilirik sebagai jalan lain untuk melakukan reformasi birokrasi dalam modus yang lebih kreatif dan mandiri. Ini terutama banyak dilakukan oleh pemerintah daerah yang memanfaatkan peluang desentralisasi dengan baik.

Dengan kesadaran tersebut, inovasi sektor publik kemudian didorong untuk terus dikembangkan dan diperluas di segala level, baik secara kualitas maupun kuantitas. Bagaimanapun, seperti hanya reformasi birokrasi, praktik inovasi sektor publik juga memiliki banyak tantangan. Untuk itu pemerintah perlu terus didorong agar mengembangkan kebijakan yang semakin memudahkan organisasi publik dalam berinovasi. Reformasi birokrasi dan inovasi sektor publik adalah dua jalur yang harus ditempuh secara simultan untuk memperbaiki birokrasi secara keseluruhan.

Dengan mengakui inovasi sebagai bagian dari reformasi birokrasi, maka impian untuk menuju pemerintah berkelas dunia mendapatkan aksentuasi baru dengan perhatian kepada pencarian solusi atas setiap masalah yang muncul dan pembaruan tanpa henti terhadap penyelenggaraan pemerintahan pada umumnya dan pelayanan publik pada khususnya. Strategi ini diharapkan memberi gairah baru bagi pembuat dan pelaksana kebijakan untuk menciptakan perubahan dalam arah yang kreatif dan variatif. 


\section{Daftar Pustaka}

Buku

Dwiyanto, Agus. 2015. Reformasi Birokrasi Kontekstual: Kembali ke Jalur yang Benar. Yogyakarta \& Jakarta: Gadjah Mada University Press \& LAN.

Farazmand, Ali. 2002. "Administrative Reform and Development: An Introduction", dalam Ali Farazmand (ed). Administrative Reform in Developing Nations. Westport: Praeger.

Rencana Pembangunan Jangka Menengah Nasional 2015 - 2019 Buku I Agenda

Pembangunan Nasional.

Rencana Pembangunan Jangka Menengah Nasional 2015 - 2019 Buku II Agenda Pembangunan Bidang.

Rencana Pembangunan Jangka Menengah Nasional 2015 - 2019 Buku III Agenda Pembangunan Wilayah.

Rohdewold, Rainer. 2005. "Indonesia", dalam Jack Rabin (ed). Encyclopedia of Public Administration and Public Policy. Boca Raton: Taylor \& Francis Group.

Suripto dan Antonius Galih Prasetyo, "Memahami Inovasi Administrasi Negara", dalam Septiana Dwiputrianti dkk (ed), 2014, Handbook Inovasi Administrasi Negara, Jakarta: Pusat Inovasi Tata Pemerintahan LAN.

Sutherland, Heather. 1979. The Making of Bureaucratic Elite: The Colonial Transformation of the Javanese Priyayi. Singapore: Asian Studies Association of Australia (ASAA) and Heinemann Educational Books.

\section{Artikel}

Binci, Daniele. 2011. "Climate for Innovation and ICT Implementation Effectiveness: A Missing Link in Italian E-government Projects." International Journal of Public
Administration, Vol. 34, No. 2, hal. 49-53.

Boyne, George A dkk. 2005. "Explaining the Adoption of Innovation: An Empirical Analysis of Public Management Reform". Environment and Planning C: Politics and Space, Vol. 23, No. 5, hal. 419-435.

Campbell, Tim E.J., Innovations and Risk Taking: The Engine of Reform in Local Government in Latin America and the Caribbean, 1997, Washington, D.C.: World Bank.

Cummings, Clare. 2015. "Fostering innovation and Entrepreneurialism in Public Sector Reform". Public Administration and Development, Vol. 35, No. 4, hal. 315-328.

Fanida, Eva Hany, dan Fitrotun Niswah. 2015. "Government Resource Management System (GRMS): Inovasi Layanan Publik dalam Pengelolaan Keuangan Daerah di Pemerintah Kota Surabaya." Jurnal Administrasi Publik, Vol. 12, No. 1., hal. 35-43.

Gow, James Iain. 2012. "Administrative Reform", dalam Louis Côté dan JeanFrançois Savard (ed). Encyclopedic Dictionary of Public Administration (online), www.dictionnaire.enap.ca.

https://www.freshconsulting.com/what-isinnovation/ (diakses 27 Januari 2017).

Lee, Hahn-Been. 1970. "An Application of Innovation Theory to the Strategy of Administrative Reform in Developing Countries." Policy Sciences, Vol. 1, No. 2, hal. 177-189.

Maddock, Su. 2009. "Gender Still Matters and Impacts on Public Value and Innovations and the Public Reform Process". Public Policy and Administration, Vol. 24, No. 2, hal. 141-152.

Mele, Valentina. 2010. "Innovation Policy in Italy (1993-2002): Understanding the Invention and Persistence of a Public Management Reform." Governance, Vol. 32, No. 2, hal. 251276. 
Pusat Inovasi Pelayanan Publik LAN, Penyusunan Profil Best Practices PTSP Sintesa Model Pelayanan Perizinan Beyond PTSP, 2015, Jakarta: Pusat Inovasi Pelayanan Publik LAN.

$$
\text { Penyusunan Model }
$$

Pengukuran Indeks Inovasi

Pemerintah Daerah, 2016, Jakarta: Pusat Inovasi Pelayanan Publik LAN.

Wibawa, Samodra, Antonius Galih Prasetyo, dan Luqman Atyatur Kautsar. 2012. "Sejarah Kebijakan dan Pemikiran Reformasi Administrasi di Indonesia', dalam Paulus Israwan dkk (ed). Transformasi Sosial dan Budaya di Indonesia. Purwokerto: Universitas Jenderal Soedirman.

Wynen, Jan, Koen Verhoest, dan Bjorn Kleizen. 2017. "More Reforms, Less Innovation? The Impact of Structural
Reform Histories on InnovationOriented Cultures in Public Organizations". Public Management Review, Vol. 19, No. 8, hal. 11421164.

Ziadi, Ahmad Rizka, Bambang Supriyono \& Andy Fefta Wijaya. 2016. "The Effectiveness of Information System in Public Complaint Service: An Implementation of E-Government Based on Jakarta Smart City Applications." International Journal of Management and Administrative Sciences, Vol. 3, No. 9, hal. 57-62.

\section{Peraturan Perundangan}

Undang-undang Nomor 23 Tahun 2014 Pemerintahan Daerah. 30 September 2014. Lembaran Negara Republik Indonesia Tahun 2014 Nomor 244. Jakarta. 